\title{
Study on Capability-oriented Teaching Mode of Business Majors in Private Universities
}

\author{
Hao Gao ${ }^{1, a}$, Guilan Sun ${ }^{1, b}$ \\ ${ }^{1}$ College of Business, Qingdao University of Technology, Qingdao, 266300, China \\ aemail, bemail
}

Keywords: Private University, Teaching Mode, Capability-Oriented

\begin{abstract}
For private universities to cultivate innovative qualified business talents, it is necessary to reform the existing teaching mode. In this paper, first introduce the concept of capability-oriented teaching mode, demonstrate necessity of capability-oriented teaching mode implement, construction of capability-oriented teaching mode from the aspects of teaching objectives and contents, teaching process, teaching evaluation, then put to use in the actual teaching. Through the teaching effect of this mode, we find it useful to stimulate the students' intrinsic motivation, useful to help students enhance the ability of operation. At last, bring forward some problems we should pay attention to about the implementation of capability-oriented teaching mode.
\end{abstract}

\section{Introduction to Capability-oriented Teaching Mode}

Capability-orientation is the general term of education, training and practice based on ability training. Ability training is the core of modern higher education. Capability-oriented teaching mode is to divide the general business teaching into three parts: classroom teaching, practice and ability. Classroom teaching in class, practice and training after class, the ability to display in the competition, on the stage, in the practice base and employing units. The teacher is responsible for classroom teaching, practical and training guided by the school teacher or industry experts who have experienced in business units, the ability to show and carried out by the students to participate in national business competitions, school stage and class presentation and to practice base and employer internship. Through the classroom theory teaching, practical training and ability to demonstrate in the form of mutual penetration and integration, to complete the whole process of teaching, improve the ability of business students.

\section{Necessity of Carrying out Capability-oriented Teaching Mode}

The National Educational Reform and Development Plan of Medium and Long Term (2010-2020) proposed that colleges and universities should optimize the knowledge structure, enrich the social practice, and strengthen the cultivation of college Students' ability. Therefore, in the daily teaching, we should use the teaching reform, focusing on the improvement of students' ability, including the ability of practice, innovation and entrepreneurship, teamwork ability. Business major of private universities should proceed from their own actual situation, focusing on the training of application ability of professional courses, change tendency of too much emphasis on imparting knowledge, should be from a simple focus on imparting knowledge to guide students to master practical skills. Capability- oriented teaching mode is an important means to realize the goal of training applied talents.

Construct the Capability-oriented teaching mode for the purpose of improving the comprehensive quality of business students, is of both theoretical value and practical value to guide the school-running practice of private universities. The Capability-oriented teaching mode, summarize a set of private colleges and universities talent training goal to adapt, but also reflects the business characteristics of the professional training teaching mode, and in practice, cultivate the applied talents of local economic development needs. 


\section{Establishment of Capability-oriented Teaching Mode}

Based on the research of the College of Business in Qingdao University of Technology, through the exploration of teaching objectives and contents, teaching process, teaching evaluation and so on, the author constructs the Capability-oriented teaching mode.

Teaching Objective and Content. Through the course teaching, the students are required to master the basic knowledge, master the basic skills related to the course, and achieve the goal of cultivating application-oriented talents with high quality and innovative consciousness. The teaching content is the traditional classroom teaching divided into three blocks, namely class theory and methods, practice and training simulation, class ability display platform to practice real power, show the effectiveness of "Capability-oriented" teaching mode. In the course of teaching, teachers can develop students' visual field and stimulate the creativity of the students, produce a subtle enlightenment through the promotion of the situation simulation. The specific requirements are as follows: the basic courses can be selectively used to simulate the situation of teaching methods.The professional courses must be used to simulate the situation of teaching methods. Teachers in the curriculum, in addition to teaching theoretical knowledge, but also to retain students display time through role-playing to practice, which are highlighting the ability. The purpose is to allow students to participate in the study of the theoretical knowledge of drilling. This lively and vivid teaching methods, provide a platform for students to improve application ability, enthusiasm can arouse learners, help students combine theory with practice. They improve their own quality to cultivate students' practical ability. The final result of teaching is demonstrated by the ability of students, and it returns to the essence of business.

Teaching Process. To cultivate application-oriented talents with high quality and innovative consciousness of the target, combined with the characteristics of private universities, teachers are required to actively carry out the curriculum reform, from the "International Business Negotiation", "Business Etiquette Training", "Network Marketing", "Customer Relationship Management" of the implementation of Capability-oriented teaching mode include class teaching theory knowledge, competition to enhance the practical ability after class (Table 1). In addition, teachers should be encouraged to apply for teaching reform projects, and actively carry out the publication of academic papers and teaching materials, so as to achieve the mutual integration and development of teaching and scientific research. Teachers should actively guide students to participate in social practice, practical skills competition, to be a good mentor.

Table 1. Capacity demonstration platform of some courses

\begin{tabular}{|c|c|c|}
\hline Number & Course name & Capacity demonstration platform \\
\hline 1 & International Business Negotiation & Simulation contest of international business negotiation \\
\hline 2 & Business Etiquette Training & Melodrama of business etiquette \\
\hline 3 & Network Marketing & Network marketing contest \\
\hline 4 & Customer Relationship Management & Contest of customer relationship management \\
\hline
\end{tabular}

Teaching Evaluation. Teaching evaluation is based on the teaching objectives, the use of teaching quality evaluation indicators, the process of whole teaching and the results of the value judgment, playing a role in teaching decision-making services. Teaching evaluation plays a role of supervisor and examiner in curriculum reform, teaching reform. Teaching evaluation is an important mode to test the success of curriculum and teaching reform. Capability-oriented teaching mode focus on the improvement of students' ability, so evaluation methods are diversified, including small test, test, compute based test, writing paper, ability display. The Capability-oriented teaching model can 
stimulate the students' inner motivation, fully mobilize their enthusiasm to participate in learning, and enhance the ability of all aspects.

\section{Effect of Capability-oriented Teaching Mode in College of Business of Qingdao University of Technology}

The research group designed the questionnaire for the students who have been accepted the Capability-oriented teaching mode. A total of 345 questionnaires were sent out, and a total of 329 questionnaires were recovered, with a recovery rate of $95.45 \%$. Among them, 319 valid questionnaires, the effective rate of $97.14 \%$. The high recovery rate and high efficiency of questionnaires ensure the authenticity of the survey results. Through the curriculum learning which implementate Capability-oriented teaching mode, there are $45.95 \%$ of the students' expression ability has improved significantly, $54.05 \%$ of the students' teamwork ability has improved significantly, $48.65 \%$ of the students' practice ability has improved significantly, $43.24 \%$ of the students' innovation and entrepreneurial ability has improved significantly, the motive power of $43.24 \%$ of the students' obtain the relevant occupation qualification certificate has significantly improved, $40.54 \%$ of the students' motivation to participate in various academic competitions at all levels has significantly improved, $43.24 \%$ of the students' motivation to participate in the students' science and technology innovation project has significantly improved, $45.95 \%$ of the students' motion to publish academic papers has significantly improved. It can be seen that through the application of the Capability- oriented teaching mode, the students' ability in all aspects has been improved, the content of each course has been mastered, and basic skills related to each course has been mastered proficiently.

\section{Encountered problems of Carrying out the Capability-oriented Teaching Mode}

Backward Teaching Concept. Students who after college entrance examination into the colleges and universities, think colleges and universities is a paradise, on their own strict requirements have been reduced, did not spend more time on their studies. Some students think that the classroom should be the teacher lectures, all teachers as the center, ignoring the subjective initiative of students. In fact, the application of the University, classroom teaching is particularly important, should actively promote the curriculum reform, so that all students put into the classroom teaching.

Limited Class Time. In the application classroom, teachers introduce both the principle, method, and practice operation, not much time for students to practice and training, the ability to show.Many students do not actively join the team exercise, resulting no confidence in the ability to show, do not achieve the original goal.

Insufficient Two-qualification Teachers. In our country, the business major education of the private universities with bachelor degree programs is based on the employment. The training goal is the innovative application-oriented talents. It requires that teachers must be two-qualification teachers combined theory and practice. The major teachers as professional expert can stand firm in the platform, to the students more targeted and persuasive in the course of teaching, so students and teachers interact with each other, and can achieve integration of production and education. In reality, the proportion of two-qualification teachers is low in the business major of private universities with bachelor degree programs. Most of the teachers are directly from the school after graduation to become a young teachers. The lack of two-qualification teachers, cause practice link is not prominent in curriculum, empty talk phenomenon is relatively common.

\section{Countermeasures to the Problems of the Capability-oriented Teaching Mode}

Update Education Ideas. The core of cultivate application-oriented talents is curriculum, and the key of the implement effectiveness of the curriculum is teaching and learning. Teachers should teach-by-doing, let students do themselves, cultivate the students' manipulative ability, combine use 
of hand and brain. The students should learn by doing, learning to do, know how to do, learn and do. The face of the ever-changing social demand environment, should assess the situation, seize the opportunity, optimize the curriculum system, renew teaching content, improve the quality of talent cultivation. To speed up the reform of the curriculum system as a whole, intensify the reform on the core issues such as talent cultivation, subject characteristics and so on, in order to improve the level of teach research, make benefit on talent cultivation.

Make Full Use of Spare Time. The implementation of Capability-oriented teaching mode, teachers and students need to make full use of spare time, repeated the exercise, really grasp the essence of each course, practical operation of each business, then the students will become application-oriented talents with high quality and innovative consciousness.

Build Teaching Teams of Two-qualification Teachers. Teachers should pay attention to integrating theory with practice, communicate with enterprises expert and teachers from other universities, familiar with the current hot issues, improve their ability. The smoothly implementation of the Capability-oriented teaching mode, need to set up teaching team including full-time teachers and industry experts, make full-time teachers to become two-qualification teachers. Teachers should teach the knowledge and skills related to current professional courses to students, and through occupation training, guiding students to participate in social practice, enhance ability in all directions of business students.

\section{Acknowledgement}

This research was the result of Research Project of Teaching Reform of Undergraduate Universities in Shandong Province in 2015 named Research and Practice of Capability-oriented Teaching Mode of Business Majors in Private Universities (Grant No. 2015M079). It was also the result of the project named Development Countermeasure Research on Foreign Trade Enterprises in Qingdao under the Environment of Cross-border E-commerce supported by the Chairman Foundation of Qingdao University of Technology in 2016 (Grant No. 2016KY006).

\section{References}

[1] Yao Jixiang. Study of Teachers' Lack of Practice Teaching Capability in Application-Oriented Colleges and the Countermeasures [J]. Journal of Hefei University of Technology (Social Science), 2010, 24(3): 139-142.

[2] Wang Jiwei. Build marketing practice teaching system based on capability-oriented [J]. Journal of Jiamusi Vocational Institute, 2015(9): 243+245.

[3] Lv Junwei, Wang Dongmei. The Course Teaching Method Based on Capability Requirement and Its Application Study in Post Oriented Education [J].Higher Education Forum, 2010(12): 42-44+67.

[4] Dai Xiuying. Study on the Capability-oriented Teaching Mode in Marketing Curriculum [J]. Journal of Changchun University of Science and Technology (Social Sciences Edition), 2010, 23(4): 154-155. 